\title{
Harvest Anticipation, Yield and Economic Feasibility of Wheat by Application of Non-Selective Herbicides
}

\author{
Glauber Monçon Fipke \\ Eng. Agrônomo, prof. Doutor Universidade Federal do Pampa (UNIPAMPA), Brazil
}

Vinicius dos Santos Cunha, Evandro Ademir Deak, Jessica Deolinda Leivas Stecca

Universidade Federal de Santa Maria, Brazil

João Leonardo Fernandes Pires

Empresa Brasileira de Pesquisa Agropecuária, Brazil

Guilherme de Almeida Arismendi, Eduarda Grün, Thomas Newton Martin

Federal University of Santa Maria, Brazil

Received: December 9, 2020 Accepted: February 12, $2021 \quad$ Published: March 9, 2021

doi:10.5296/jas.v9i2.18046

URL: https://doi.org/10.5296/jas.v9i2.18046

\begin{abstract}
The present work aims to evaluate the possibility of anticipating the wheat harvest by the application of non-selective herbicides in the pre-harvest conditions, thereby providing productive and economic viability. In total, 13 treatments were executed, which includes the spraying of different herbicide combinations (glufosinate-ammonium, glyphosate, and paraquat) in the phenological stages (Z-83, Z-85, Z-87, Z-92), and treatments without application of herbicides. Further, the treatment step was followed by providing different harvest conditions such as (i) glufosinate-ammonium: 9.5 and 8.8 days, (ii) glyphosate: 11.2 and 10.9 days, and (iii) paraquat: 7.9 and 8.5 , where the first numerical value corresponds to number of days for the year 2016 followed by 2017. A mean reduction in seed yield of $4.6 \%$ (BRS Parrudo) and $25.4 \%$ (TBIO Sinuelo) was observed upon application of herbicides in the first two phenological stages. Additionally, an economic loss reaching up to R $\$ 2512 \mathrm{ha}^{-1}$, was demonstrated. Therefore, the application of the non-selective herbicides glufosinate-ammonium and paraquat in the pre-harvest results in wheat phytointoxication,
\end{abstract}


however, promoting harvest anticipation in 4.8 and 5.3 days, respectively.

Keywords: wheat, harvest anticipation, glufosinate-ammonium, glyphosate, paraquat

\section{Introduction}

For achieving sustainable agriculture, utilization of the cropping seasons with winter-summer crops in the finest way is highly essential. A consolidated example is the wheat-soybean binomial, which grows mainly in the south of Brazil due to climate being favorable for both the crops. However, it has been trailing behind as only $8.18 \%$ of 5.6 million hectares area, where soybeans are made to grow in the Rio Grande do Sul (RS), is destined for the production of wheat in winter (Conab, 2018).

Owing to early sowing the tendency of wheat crop to undergo damages caused by frost on the heading/flowering stage increases (Rodrigues et al., 2011; Cadenas et al., 2020). In order to surmount this situation, agroclimatic zoning pointed out the preferential sowing season to fall within the middle to the end of the interval (Embrapa, 2018). Therefore, due to an overlap of the area occupation period of both wheat and soybean crops, an alarming situation occurs which inflicts a penalty on both the crops regarding their productivity/quality (Pires et al., 2016). In addition, the time elapsed between physiological maturity and harvest allows fusarium infection which is a major cause of mycotoxins (Edwards et al., 2018; Janssen et al., 2019). And climate change is sometimes increasing the frequency of precipitation in some regions, especially at harvest time (Song et al., 2019). This is why early harvesting is crucial to prevent such contamination.

With the aim of making the system practically feasible, non-selective herbicides as desiccants have been used in few studies which facilitate in anticipating the crop harvesting time (Yenish \& Young, 2000). Since this practice does not reduce the yield of wheat grains, hence it can be exploited as an alternative for seed production (Bellé et al., 2014). Additionally, pre-harvest desiccation can lead to several indirect benefits such as (i) bestowing higher yields of the mechanized harvesting operation and (ii) controlling late-occurring weeds (Griffin et al., 2010). Thus, the properties must be sustainable from the productive, economic and environmental point of view, in order to carry out herbicide management to allow crop production (Lodovichi et al., 2013).

More accurate and current information is required regarding the (a) choice of the mechanism of action, (b) the dose of the active ingredient by area, and (c) the definition of the moment of application (Krenchinski et al., 2017). Apart from these, elucidation of several other aspects such as (i) the impact on the characters of production, (ii) technological quality, (iii) physical, physiological and sanitary quality, (iv) residual of pesticides, is essential. However, some authors report that non-selective herbicide applications such as non-preharvest glyphosate do not affect the primary and secondary structure of wheat gluten proteins, although the molecular weight of mainly SDS extractable and unextractable proteins can be affected, especially when applied at the soft dough stage (Malalgoda et al., 2020a). Although they are banned in Brazil. Other research indicates that systemic herbicides accumulate more in wheat seeds (Perboni et al 2018). Some characteristics of wheat grains were affected by the 
application of glyphosate in pre-harvest. Features such as: number of drops, protein content percentage of flour extraction, glutem moisture and gluten index. Applications in the soft mass stage caused a profound reduction in the mass of a thousand grains of wheat, indicating that early applications cause a decrease in grain productivity (Malalgoda et al., 2020b).

Thus, bearing in mind above observations, the present investigation aims to evaluate the possibility of anticipating wheat harvest by the application of non-selective herbicides in the pre-harvest, providing productive and economic viability.

\section{Methodology}

\subsection{Experimental Site}

For carrying out the experiments, an experimental area was selected, which belonged to the Crop Science department, located in the Universidade Federal de Santa Maria, Santa Maria, Rio Grande do Sul. Geographically it is found to be located at $29^{\circ} 43^{\prime} 2.81^{\prime \prime S}$ south latitude, $53^{\circ} 43^{\prime} 58.28^{\prime \prime} \mathrm{W}$ west longitude and 116 meters of altitude. The soil in the area was classified as Argissolo Vermelho distrófico arênico (sandy clay loam Acrisol, according to FAO classification). Soil samples were collected at a depth of $0,0-0,10$ to $0-20 \mathrm{~cm}$ for chemical characterization and the results were as follows: $\mathrm{pH}$ (water, 1:1) = 5.0 - 4.6; SMP (SMP index for soil $\mathrm{pH}$ correction $)=5.1-4.6$; $\operatorname{organic}$ matter $(\%, \mathrm{~m} / \mathrm{v})=2.9-1.6$; clay $\left(\mathrm{g} \mathrm{kg}^{-1}\right)=280-$ 310; $\mathrm{P}_{2} \mathrm{O}_{5}$, P-Mehlich $\left(\mathrm{mg} \mathrm{dm}^{-3}\right)=19.0-4.1 ; \mathrm{K}_{2} \mathrm{O}\left(\mathrm{mg} \mathrm{dm}^{-3}\right)=68.0-52.0 ; \mathrm{H}+\mathrm{Al}(\mathrm{cmolc}$ $\left.\mathrm{dm}^{-3}\right)=12.3-21.8$; cation-exchange capacity $(\mathrm{CEC})\left(\mathrm{pH} \mathrm{7,} \mathrm{cmolc} \mathrm{dm}^{-3}\right)=19.7-26.3$; bases saturation $(\%)=37.7-17.0$. On the other hand, according to Köppen classification, was found to consist of $86.7 \%$ and $13.3 \%$ of the $\mathrm{Cfa}$ and $\mathrm{Cfb}$, respectively (Alvares et al., 2013), which indicated the presence of subtropical humidity with hot summers and no dry season.

\subsection{Sowing Management}

Initially, the glyphosate herbicide (Roundup ${ }^{\circledR}, 1440 \mathrm{~g}$ of active ingredient (ai) ha ${ }^{-1}$ ), was employed for weeding the volunteers continuously for 45 days before sowing. Further, for the experiment, two wheat cultivars were used (BRS Parrudo and TBIO Sinuelo). On the other hand, for the phytosanitary treatment of seeds the insecticide imidacloprid + thiodicarb (Cropstar ${ }^{\circledR}, 0.45$ and $1.35 \mathrm{~g} \mathrm{ai} \mathrm{kg}^{-1}$ seed), fungicide triadimenol (Baytan ${ }^{\circledR}, 0.405 \mathrm{~g} \mathrm{ai} \mathrm{kg}^{-1}$ seed) were used. For sowing, which was carried out on June 23, 2016, and June 22, 2017, seed sowing machine equipped with seed metering and mineral fertilizer was utilized, leading to the implantation of 300 seedlings $\mathrm{m}^{-2}$, in total with the application of $400 \mathrm{~kg} \mathrm{ha}^{-1}$ of fertilizer $\left(\mathrm{N}-\mathrm{P}_{2} \mathrm{O}_{5}-\mathrm{K}_{2} \mathrm{O}, 05-20-20\right)$ with furrows spaced at $0.2 \mathrm{~m}$. Fertilization with nitrogen corresponded to the spread of $133 \mathrm{~kg}$ of proportionally equal fractionated urea $(45 \% \mathrm{of} \mathrm{N}$ ) ha-1 in three phenological stages (Zadoks et al., 1974), at tillering (Z-20), and the elongation of the stem (Z-30 and Z-37).Further, the application of fertilizer was in accordance to the recommendation based on the interpretation of soil chemical analysis for $0.10 \mathrm{~m}$ depth with an expected harvest of $5 \mathrm{t}$ of $\mathrm{ha}^{-1}$ seeds. Phytosanitary management of pests (weeds, insects and diseases) was carried out according to the technical indications (Embrapa, 2018). 


\subsection{Experimental Design and Treatments}

With the aim of further attesting the homogeneity, followed by prevention of a priori errors, evaluations were carried out in all the plots of the experiment prior to the application of the treatments cautiously. For this purpose, the number of plants, tines, and spikes per area and the mass of spikes, were quantified from the plants collected $\left(0.8 \mathrm{~m}^{2}\right)$ per plot with the subsequent rejection of plots exhibiting variation. The experimental unit was composed of an area having the dimension of $7.75 \mathrm{~m} \times 2 \mathrm{~m}$, totaling $15.5 \mathrm{~m}^{2}$, with the experiment design consisting of a random block with five replicates, followed by analysis of two cultivars separately. In totality 13 treatments (including one treatment without application) were performed. Each treatment was composed of a combination of herbicides along with their application at various phenological stages. For these treatments, the herbicides employed were, (i) glufosinate-ammonium (Finale ${ }^{\circledR}, 350 \mathrm{~g}^{\text {i.a. }} \mathrm{ha}^{-1}$ ), (ii) glyphosate (Stinger ${ }^{\circledR}, 1440 \mathrm{~g}$ i.a. $\mathrm{ha}^{-1}$ ), and (iii) paraquat $\left(\right.$ Gramoxone ${ }^{\circledR}, 400 \mathrm{~g}^{\text {i.a. }} \mathrm{ha}^{-1}$ ). Furthermore, the phenological stages of application of these herbicides were: (a) Z-83 (seed starting mass texture and green coloration, sticky contents when kneaded by thumb pressure), (b) Z-85 (soft-mass seed with light green color, when pressed with the nail of the thumb the mark disappears quickly), (c) Z-87 (hard mass seed of light red color, upon pressing with the thumbnail the mark remains intact), and (d) Z-92 (very hard red color seed, need to be kneaded by the pressure of the thumb). Thus, by evaluating the ears randomly in at least $50 \%$ of the plants of the plot, the definition of the term "phenological stage" was established. Instead of adjuvants and surfactants, the potable water fills the spray. Moreover, $\mathrm{CO}_{2}$ pressurized spray with calibration proportional to a volume of $150 \mathrm{~L} \mathrm{ha}^{-1}$ at $200 \mathrm{kPa}$ pressure, were employed for applying the treatments and the spray bar was composed of four flat jet tips (Teejet ${ }^{\circledR} \mathrm{XR}$ 100.02) spaced $0.5 \mathrm{~m}$ apart.

\subsection{Data Collection}

The herbicide treatment was followed by the estimation of phytotoxification (\%) via visual analysis after every two days, continued till the 12th day, using a chart of notes (Velini et al., 1995). The absence of injuries to the culture was denoted by "note 0 ", where as "note 100" stands for the death of $100 \%$ of the wheat plants. Further, the anticipation of the harvesting point after herbicide application (AHPAHA, days) and anticipation of harvesting point comparing treatment without herbicide application (AHPCWHA, days) was quantified, with the harvesting point defined by the maturation of at least $95 \%$ of the spikes, pale color, and decumbent curvature.

In each experimental unit six $\mathrm{m}^{2}$ was manually collected threshed and mechanically cleaned. For the estimation of seed yield ( $\mathrm{kg} \mathrm{ha}^{-1}$ seeds), the water content (base 13\%) was calculated using a semianitic balance. Further, for measuring seed moisture after harvest (UM,\%) and mass of hectoliter (MH, kg of $\mathrm{hL}^{-1}$ seeds) seed sampling was carried out using the $\mathrm{G650i} \mathrm{i}^{\circledR}$ automated meter (Gehaka, São Paulo, SP, Brazil). Similarly, the mass of one thousand seeds was quantified (MMS, grams) by performing eight hundred seed counts and thereby averaging the masses obtained in the subsamples. 


\subsection{Economic Analysis}

The economic viability for commercialization of seed (VECS, R $\$ \mathrm{ha}^{-1}$ ) was further determined, by calculating the difference between the monetary value invested for carrying out an agrochemical application in the pre-harvest of the crop and the monetary value of the economic return coming from the commercialization of the seeds. Conclusively, the reference cost and the relative seed yield (PSR, $\mathrm{kg} \mathrm{ha}^{-1}$ ) of treatments with herbicide application were found to be equivalent to the values obtained in the treatment without application. The costs of production were: tractor operation ( $\mathrm{R} \$ 25.08)$, tractor depreciation ( $\mathrm{R} \$ 7.40)$, sprayer depreciation ( $\mathrm{R} \$ 10.84)$ and the purchase price / dose of the herbicides [Finale ${ }^{\circledR}(\mathrm{R} \$ 101.50)$, Stinger $^{\circledR}(\mathrm{R} \$ 39.00)$ and Gramoxone $\left.{ }^{\circledR}(\mathrm{R} \$ 48.00)\right]$. It was considered as revenue value $\mathrm{R} \$ 1.40 \mathrm{~kg}^{-1}$ of wheat sold as seed. These numbers were based on Brazilian production costs for the year 2016 (Conab, 2016).

\subsection{Data Analysis}

The data from the analyzed variables were examined with subsequent estimation of error normality, variance homogeneity and model additivity using the Shapiro-Wilk, Bartlett and non-Tukey additive tests, respectively. Further, the joint variance analysis was performed [F test $(p \leq 0.05)]$ on experiment composed of 13 treatments carried out for two years. Subsequently, the complementary clustering test was executed [Scott-Knott $(\mathrm{p} \leq 0.05)]$ using Software Action ${ }^{\circledR}$ (Estatcamp, São Carlos, SP, Brazil) and Genes ${ }^{\circledR}$ (Cruz, 2013).

\section{Results and Discussion}

In the case of BRS Parrudo, and some variables of the TBIO Sinuelo cultivar the variance analysis indicated no interactions between the treatments and the years in which the experiments were carried out. The mean values of the variables analyzed are tabulated (Table 1) with the further depiction in Figure 1 and 3. For the determination of the phytotoxification, only TBIO Sinuelo cultivar was considered, due to some technical and labor reasons. In most cases, the treatments with glufosinate-ammonium and paraquat herbicides were found to be more efficient (Figure 1). Further, the experiment of 2016 showed greater anticipations in comparison to the second experimental year. Upon application of the herbicide, the time of anticipation of the harvest point was found to get influenced by the phenological stage in which this management was carried out. Following the herbicide application step, different harvest conditions were provided such as (i) glufosinate-ammonium: 9.5 and 8.8 days, (ii) glyphosate: 11.2 and 10.9 days, and (iii) paraquat: 7.9 and 8.5, where the first numerical value corresponds to number of days for the year 2016 followed by 2017. However, a comparison of this period in relation to the treatment with no herbicide application is imperative. 


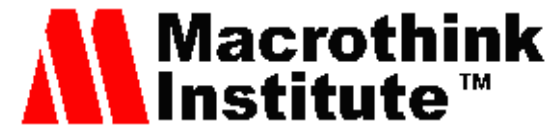

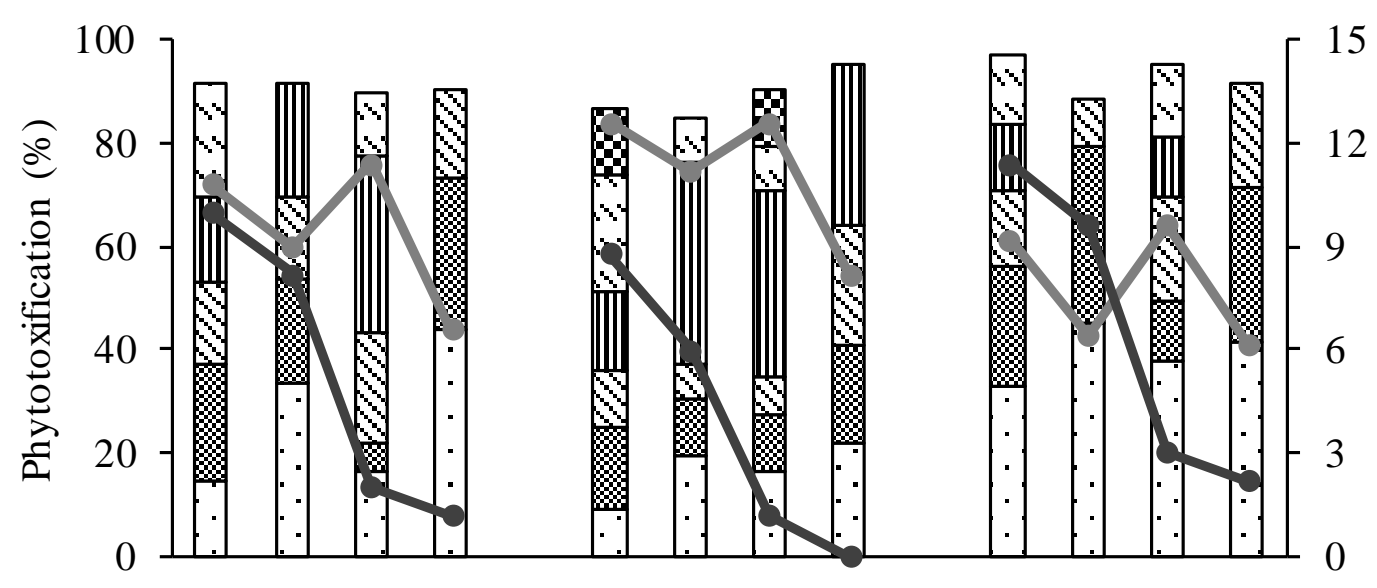

(a)

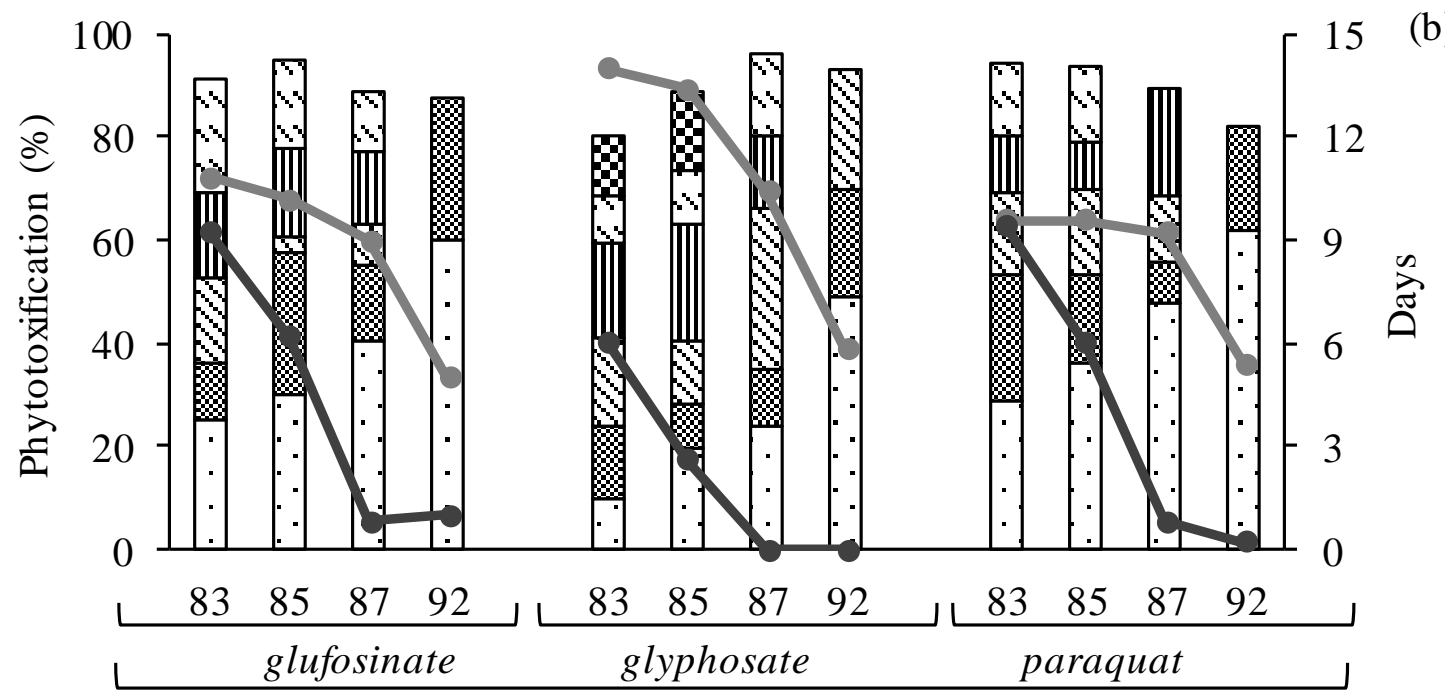

Phenological Stage (Zadoks et al., 1974)

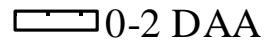

$\boldsymbol{\infty}$ 2-4 DAA
$\mathbf{\infty} 10-12$ DAA

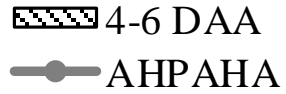

血监监 6-8 DAA

8-10 DAA

AHPAHA

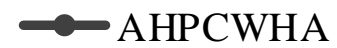

Figure 1. Phytotointoxification (\%) of wheat (TBIO Sinuelo) submitted to the application of non-selective herbicides in the pre-harvest in the 2016 (a) and 2017 (b) and anticipation of the harvest point after herbicide application (AHPAHA, days) and anticipation of harvesting point comparing treatment without herbicide application (AHPCWHA, days). Santa Maria, RS, Brazil

In other words, comparison with a normal cultivation condition without the forced maturation by the herbicide was possible. For the first year, the days of anticipation was found to be 5.4, 4, and 6.6 (2016) and 4.3, 2.2, and 4.1 (2017), for the herbicides glufosinate-ammonium, glyphosate, and paraquat, respectively. Regardless of the applied herbicide, the two early phenological stages (Z-83 and Z-85) promote greater anticipation upon treatment with the herbicide. However, in some situations such as the application of the herbicide glyphosate at the Z-92 stage, no prediction was reported. The number of days ahead of harvest means that other operations such as pre-sowing desiccation should be performed quickly and effectively, ensuring complete weed desiccation for subsequent cultivation. This is an important step to 
ensure system sustainability (Lodovichi et al., 2013).

The application of herbicides, in the pre-harvest, negatively changed the components of seed yield. Mostly, the seed yield was higher for the treatment without herbicides application, while under some circumstances it remains unchanged even in the presence of herbicides. The seed yield for the 2017 crop for the both the cultivars, and the hectoliter mass for TBIO Sinuelo cultivar, was not affected (Table 1). However, the main components of the production were influenced, by the cultivation season represented by the year in which the experiment was carried out. On the other hand, before the installation of the experiment in 2017 the population of established plants was found to decrease due to the concentration of precipitation, thereby leading to failure in the emergency. Recent researchesindicate that the characteristics of quantity and quality of wheat grains are altered mainly in earlier applications in relation to the time of harvest. As well there is the possibility that these grains or seeds have significant amounts of residues in the grains after harvest (Perboni et al., 2018; Tavares et al., 2018; Malalgoda et al., 2020a; Malalgoda et al., 2020b). Song et al. (2019), suggest that with global climate change, high rainfall may occur in some places that may alter the uniformity of sowing and harvesting of crops. Additionally, during the development cycle, the evapotranspiration of the plants increased since they were exposed, to a temperature higher than the average daily temperatures (Figure 2). Thus, one can deduce that the production of photoassimilates was reduced due to stress, as it directly interferes with production that demonstrates unsatisfactory indexes upon being compared with the previous growing season.

Table 1. Components of wheat yield (BRS Parrudo and TBIO Sinuelo) subjected to non-selective herbicide application in pre-harvest in the 2016 and 2017 crop seasons. Santa Maria, RS, Brazil

\begin{tabular}{cccccccccc}
\hline \multirow{2}{*}{ Herbicide } & $\begin{array}{c}\text { Phen. } \\
\text { Stage }\end{array}$ & \multicolumn{2}{c}{$\begin{array}{c}\text { Seed Yield } \\
\left(\mathrm{kg} \mathrm{ha}^{-1}\right)\end{array}$} & $\begin{array}{c}\text { Hectolite rmass } \\
\left(\mathrm{kg} \mathrm{hL}^{-1}\right)\end{array}$ & $\begin{array}{c}\text { Mass of } \\
\text { thousand seeds } \\
(\mathrm{g})\end{array}$ & $\begin{array}{c}\text { Seed moisture } \\
(\%)\end{array}$ \\
\hline \multirow{5}{*}{$\begin{array}{c}\text { glufosinate- } \\
\text { ammonium }\end{array}$} & Z-85 & $3843 \mathrm{~b}$ & 2202 & $74.3 \mathrm{~b}$ & $68.0 \mathrm{~b}$ & $34.2 \mathrm{~b}$ & $30.3 \mathrm{~b}$ & $16.6 \mathrm{a}$ & $12.7 \mathrm{~b}$ \\
& Z-87 & $4008 \mathrm{a}$ & 2301 & $73.3 \mathrm{~b}$ & $70.3 \mathrm{a}$ & $33.3 \mathrm{c}$ & $31.3 \mathrm{a}$ & $11.2 \mathrm{~d}$ & $12.6 \mathrm{~b}$ \\
& & & -2016 & 2016 & 2017 & 2016 & 2017 & 2016 & 2017 \\
\hline & Z-92 & $4140 \mathrm{a}$ & 2264 & $74.0 \mathrm{~b}$ & $70.7 \mathrm{a}$ & $34.8 \mathrm{~b}$ & $31.3 \mathrm{a}$ & $11.1 \mathrm{~d}$ & $12.4 \mathrm{~b}$ \\
\hline & Z-83 & $3928 \mathrm{a}$ & 2189 & $73.4 \mathrm{~b}$ & $68.9 \mathrm{~b}$ & $32.0 \mathrm{c}$ & $29.9 \mathrm{~b}$ & $13.8 \mathrm{~b}$ & $14.3 \mathrm{a}$ \\
& Z-85 & $4178 \mathrm{a}$ & 2219 & $73.5 \mathrm{~b}$ & $69.0 \mathrm{~b}$ & $33.3 \mathrm{c}$ & $30.3 \mathrm{~b}$ & $15.7 \mathrm{a}$ & $12.8 \mathrm{~b}$ \\
& Z-87 & $4144 \mathrm{a}$ & 2211 & $75.7 \mathrm{a}$ & $69.4 \mathrm{~b}$ & $34.3 \mathrm{~b}$ & $31.8 \mathrm{a}$ & $11.2 \mathrm{~d}$ & $12.0 \mathrm{~b}$ \\
& Z-92 & $3989 \mathrm{a}$ & 2283 & $75.6 \mathrm{a}$ & $70.7 \mathrm{a}$ & $34.4 \mathrm{~b}$ & $32.0 \mathrm{a}$ & $11.0 \mathrm{~d}$ & $12.7 \mathrm{~b}$ \\
\hline
\end{tabular}




\begin{tabular}{cccccccccc} 
& Z-83 & $3534 \mathrm{~b}$ & 2195 & $73.8 \mathrm{~b}$ & $69.3 \mathrm{~b}$ & $30.3 \mathrm{~d}$ & $30.6 \mathrm{~b}$ & $13.2 \mathrm{c}$ & $13.0 \mathrm{a}$ \\
paraquat & Z-85 & $3779 \mathrm{~b}$ & 2238 & $73.9 \mathrm{~b}$ & $68.6 \mathrm{~b}$ & $32.0 \mathrm{c}$ & $31.2 \mathrm{a}$ & $15.2 \mathrm{a}$ & $13.8 \mathrm{a}$ \\
& Z-87 & $3806 \mathrm{~b}$ & 2227 & $73.0 \mathrm{~b}$ & $68.5 \mathrm{~b}$ & $33.3 \mathrm{c}$ & $31.5 \mathrm{a}$ & $11.2 \mathrm{~d}$ & $12.1 \mathrm{~b}$ \\
& Z-92 & $3991 \mathrm{a}$ & 2282 & $73.5 \mathrm{~b}$ & $70.1 \mathrm{a}$ & $34.3 \mathrm{~b}$ & $31.6 \mathrm{a}$ & $11.4 \mathrm{~d}$ & $12.4 \mathrm{~b}$ \\
\hline Without application & $4176 \mathrm{a}$ & 2349 & $75.9 \mathrm{a}$ & $70.9 \mathrm{a}$ & $36.8 \mathrm{a}$ & $31.8 \mathrm{a}$ & $11.3 \mathrm{~d}$ & $12.4 \mathrm{~b}$ \\
\hline \multirow{5}{*}{ glufosinate- } & Z-85 & $4221 \mathrm{~b}$ & 1857 & $74.5 \mathrm{a}$ & 73.1 & $29.8 \mathrm{~b}$ & $27.1 \mathrm{a}$ & $21.1 \mathrm{a}$ & $13.5 \mathrm{~b}$ \\
ammonium & Z-87 & $5128 \mathrm{a}$ & 1982 & $74.8 \mathrm{a}$ & 74.1 & $31.9 \mathrm{a}$ & $27.5 \mathrm{a}$ & $13.2 \mathrm{~d}$ & $13.4 \mathrm{~b}$ \\
& & & $------------T B I O$ & Sinuelo------------- & \\
& Z-82 & $5340 \mathrm{a}$ & 1974 & $75.3 \mathrm{a}$ & 73.8 & $31.9 \mathrm{a}$ & $27.9 \mathrm{a}$ & $13.7 \mathrm{~d}$ & $13.8 \mathrm{~b}$ \\
\hline \multirow{5}{*}{ glyphosate } & $3386 \mathrm{c}$ & $1883^{\mathrm{n}}$ & $71.2 \mathrm{c}$ & $73.9 \mathrm{~ns}$ & $25.2 \mathrm{~d}$ & $26.6 \mathrm{~b}$ & $17.6 \mathrm{~b}$ & $15.2 \mathrm{a}$ \\
& Z-83 & $4190 \mathrm{~b}$ & 1795 & $75.8 \mathrm{a}$ & 73.5 & $29.1 \mathrm{~b}$ & $26.4 \mathrm{~b}$ & $14.8 \mathrm{c}$ & $14.7 \mathrm{a}$ \\
& Z-85 & $4537 \mathrm{~b}$ & 1903 & $76.3 \mathrm{a}$ & 74.2 & $29.9 \mathrm{~b}$ & $26.8 \mathrm{~b}$ & $17.1 \mathrm{~b}$ & $12.8 \mathrm{~b}$ \\
& Z-87 & $5158 \mathrm{a}$ & 1969 & $75.2 \mathrm{a}$ & 73.5 & $31.5 \mathrm{a}$ & $27.8 \mathrm{a}$ & $13.3 \mathrm{~d}$ & $13.4 \mathrm{~b}$ \\
& Z-92 & $5255 \mathrm{a}$ & 2015 & $74.9 \mathrm{a}$ & 72.9 & $31.6 \mathrm{a}$ & $27.3 \mathrm{a}$ & $13.4 \mathrm{~d}$ & $13.9 \mathrm{~b}$ \\
\hline Without application & $5077 \mathrm{a}$ & 2090 & $75.7 \mathrm{a}$ & 75.5 & $32.7 \mathrm{a}$ & $27.8 \mathrm{a}$ & $13.7 \mathrm{~d}$ & $13.7 \mathrm{~b}$ \\
\hline
\end{tabular}

* Distinct letters in the column differ from each other [Scott-Knott $(p \leq 0.05)]$; ${ }^{\text {ns }}$ not significant. 


\section{I Macrothink}
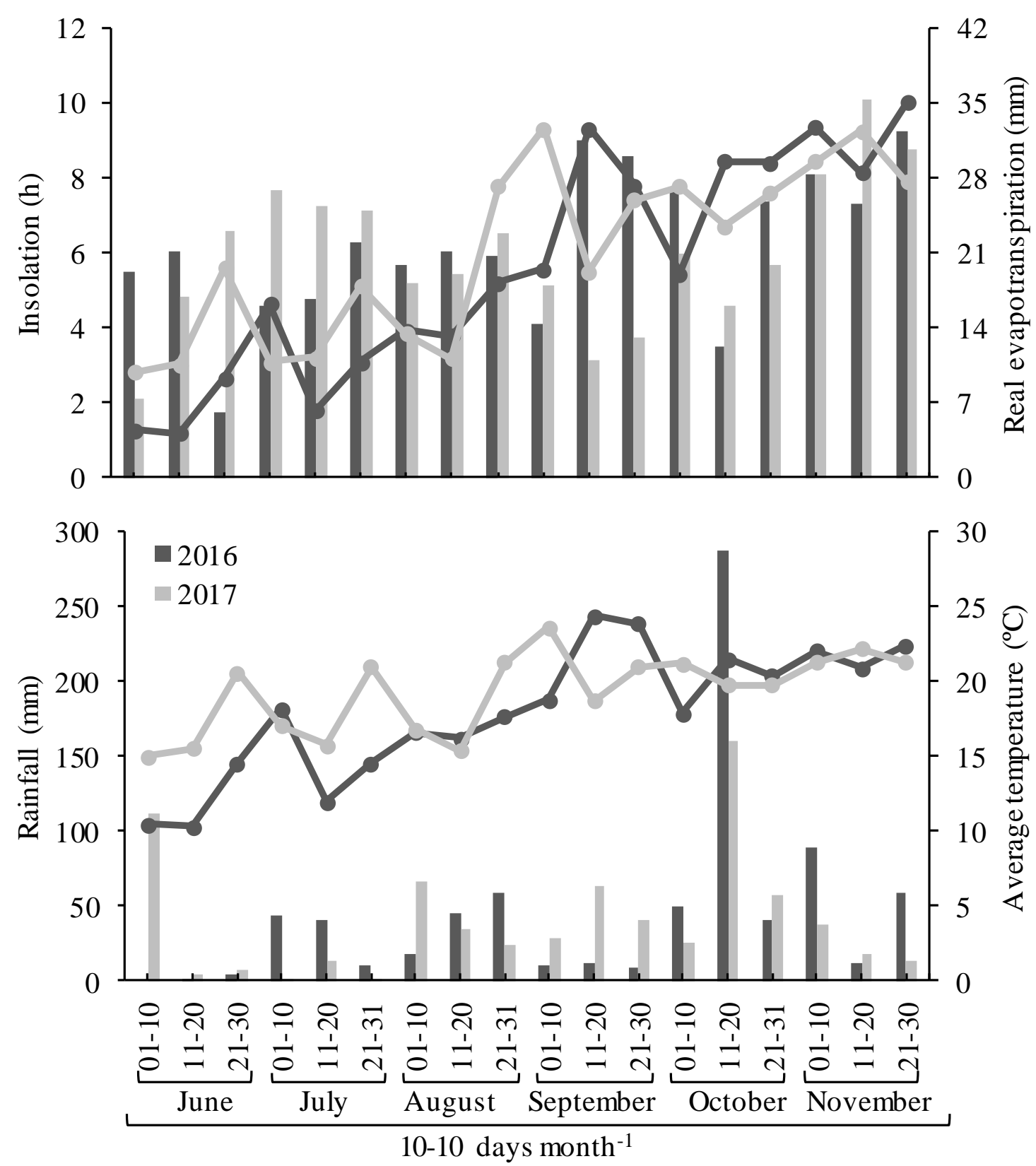

Figure 2. Insolation, rainfall (bars), real evapotranspiration and average temperature (lines).

Santa Maria, RS, Brazil

Mainly, the seed productivity was influenced to a greater extent by the phenological stage of application, where the treatments offered in earlier stages showed a greater reduction. Using the Quartzo cultivar, the application of herbicides in stages 11.2 and 11.3 of the Feeks phenological scale (Large, 1954) displays no effect on the grain yield in comparison to the control (Bellé et al., 2014). Nevertheless, for this type of study, the use of phenological scale does not seem to be adequate, as stage 11.2 comprises Z-83 to Z-87 (Zadoks et al., 1974). Since the time span of more than ten days, under field conditions, act as a determining factor leading to maturation of the culture, the precision of the information gets impaired. Contrastingly, when the herbicides glufosinate-ammonium, paraquat, glyphosate, clethodim, and diquat were applied, in the Z-80 stage, grain yield got reduced (Krenchinski et al., 2017). 
In research carried out in Brazil, there were also contrasting results, in which, for some authors, there was a reduction in grain productivity with the application of herbicides at moments before physiological maturity (Perboni et al., 2018), with accumulation of residues of systemic herbicides in grains. Meanwhile, the application of methyl metosulfuron and paraquat at any stage of grain formation does not cause accumulation of herbicides in wheat grains (Tavares et al., 2018).

Possibly, according to the recommendation of Belle et al. (2014), the loss in grain yield due to desiccation occurs with $71.8 \%$ of the wheat plants being in 11.2 stage. However, the results of the current investigation deviate from the Belle's observation, as 11.3 stage was found to coincide with the Z-91 and Z-92 stages, which exhibits no reduction in comparison to control. Further, it was validated by Krenchinski et al. (2017) for the cultivar CD 150, which expresses phenological characteristics similar to those used in the present research. For instance, both glyphosate in Z-70 (Yenish \& Young, 2000), paraquat in Z-79 indicated an increase in the grain mass moisture in $45 \%$ - $65 \%$ (Mellado \& Pedreros, 2005) promotes yield reduction. Thus, from the Z-88 stage having grain moisture content below $40 \%$, act as a more reliable indicator to avoid losses (Darwent et al., 1994). Although there are specific studies indicating that glyohosate has no effect on gluten proteins (Malalgoda., 2020a). There are effects on germination and the reduction in time to harvest is not significant, in addition to being a herbicide forbidden for this purpose in Brazil.

Statistically, for the two cultivars in the 2016 harvest, no difference was observed upon comparing the yield of seeds obtained in the treatments, in which the herbicides were employed in the Z-87 and Z-92 stages, with the treatment without application. In the first two phenological stages, the treatment provided an average reduction of $4.6 \%$ and $25.4 \%$, in BRS Parrudo and TBIO Sinuelo cultivars, respectively. Similarly, the herbicide glufosinate-ammonium (Z-83) showed an average reduction of $1308 \mathrm{~kg}$ of seeds $\mathrm{ha}^{-1}$ in the cultivar TBIO Sinuelo. Alternatively, the seed yield of the BRS Parrudo cultivar was not influenced, by the herbicide glyphosate, regardless of the phenological stage of application.

Elucidation of reduction in seed production is based on its association with the main components of productivity, which primarily includes; (a) the number of spikes per area, (b) the number of spikelets per spike, and (c) the number of seeds per spikelet (Rodrigues et al., 2011). With all these components being in the stage prior to anthesis. Since these traits were already defined at the time of application of treatment, the measurement of these characters was not carried out. However, the main component of productivity after physiological maturation was found to be the seed mass, which got reduced in the present study, upon application of herbicides. These results are comparable with the outcome of previous work that evaluated different times of treatment and herbicides (Bellé et al., 2014). Application of herbicides also causes stress in plants, which can influence various physiological processes such as translocation of photoassimilates as a function of grain filling. During the assimilation process of photosynthesis, the seeds accommodate carbohydrates in the form of starch granules (Taiz et al., 2017). Similarly, in cereals, the main structural constituent of the seed is starch. Thus, the presence of starch in seeds might be the possible reason of reduction in the mass of grains. 


\section{Macrothink}

Upon evaluating the mass of the hectoliter of the cultivar TBIO Sinuelo, the influence of herbicide on it was found to be very less since it undergoes a reduction only by the use of glufosinate-ammonium and paraquat, in stage Z-83 (2016). However, for the BRS Parrudo cultivar, the reduction was witnessed with the application of glyphosate at Z-87 and Z-92 (2016), in addition to, the use of any herbicide at the Z-92 (2017) stage. Moreover, the highest mean value was obtained for treatment without herbicide application, although there was no statistical difference. The stage of application influences the mass of one thousand seeds.

Upon treating the stages Z-87 and Z-92 with the herbicides larger seeds were obtained, whereas the reduction in seed mass mainly occurred in the Z-83 stage. On the other hand, in treatment without application, a mean reduction of 10.9 (BRS Parrudo) and $2.6 \%$ (TBIO Sinuelo) in the mass of a thousand grains was promoted by pre-harvest desiccation, being independent of the herbicide and phenological stage of application (2016). In the subsequent experiment carried out on the second crop, the reductions were maintained, at $8.7 \%$ and $2.9 \%$, in BRS Parrudo and TBIO Sinuelo, respectively.

Estimation of the economic feasibility was accomplished, by analyzing the average yield relative to the treatment without the application of herbicides in the two years of experiments. In the case of BRS Parrudo cultivar, the average seed yield was established as $4176 \mathrm{~kg}$ (2016) and $2349 \mathrm{~kg}$ (2017) of seeds ha ${ }^{-1}$. Similarly, the average seed yield for TBIO Sinuelo was found to be $5077 \mathrm{~kg}$ (2016) and 2090 (2017) $\mathrm{kg}$ of seeds ha ${ }^{-1}$. The monetary value acquired through the sale of the input, discounting the application costs, represented the economic viability (Figure 3). 


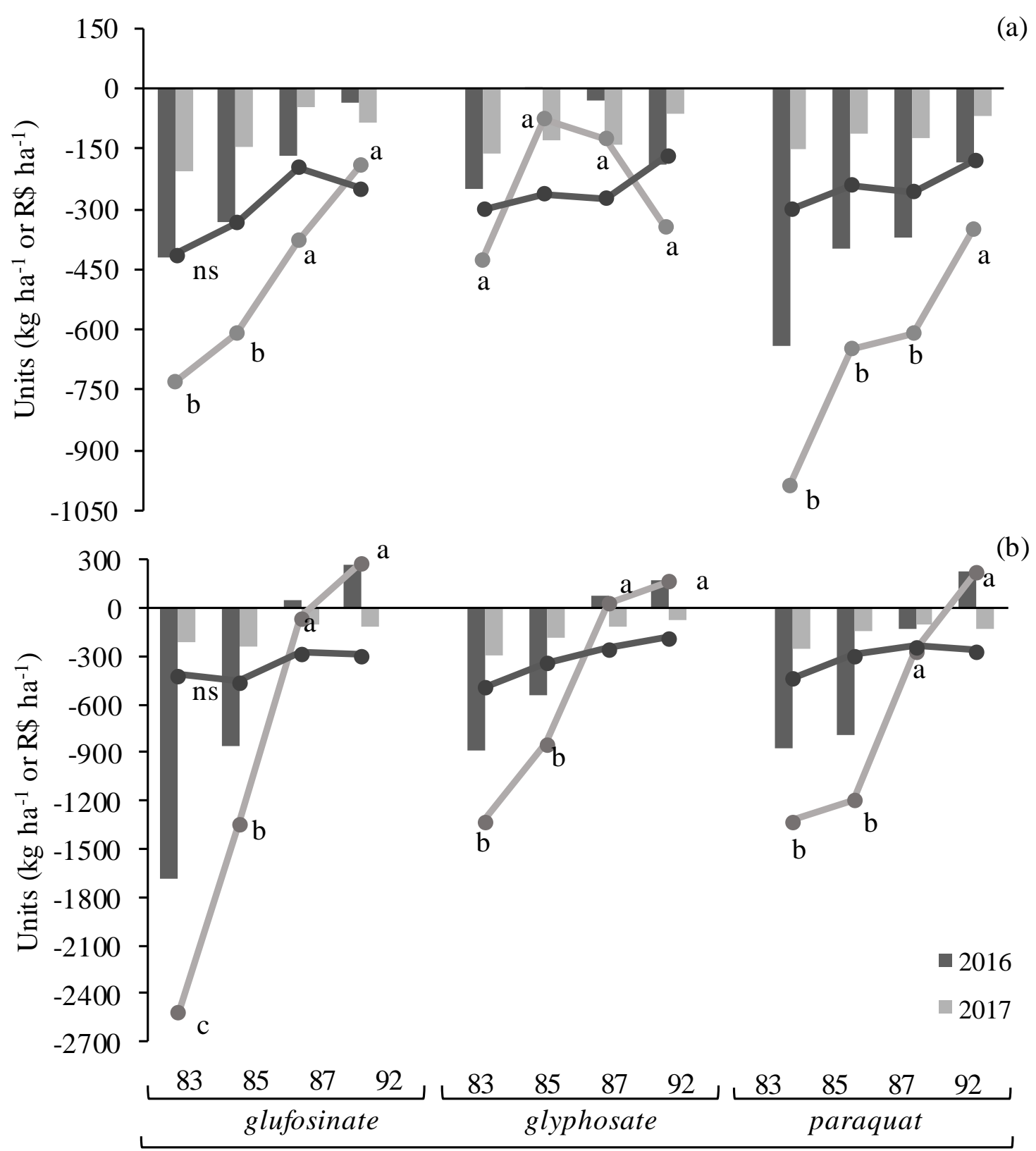

Phenological Stage (Zadoks et al., 1974)

Figure 3. Relative seed yield (bars) and economic viability in seed commercialization [BRS Parrudo (a) and TBIO Sinuelo (b)] submitted to the application of non-selective herbicides in the pre-harvest in 2016 and 2017 crop seasons. Santa Maria, RS, Brazil. The values obtained in the treatments without the application of herbicides as reference (zero). Different letters differ from each other $[$ Scott-Knott $(\mathrm{p} \leq 0.05)] ;{ }^{\text {ns }}$ not significant

However, in the BRS Parrudo cultivar, in the preharvest, no increase in the seed yield was observed with the application of herbicides. On the contrary, an average reduction of 251 and $119 \mathrm{~kg}$ of seeds ha ${ }^{-1}$, was established in the first and second year, respectively. Thus, in the case of the BRS Parrudo cultivar, no economic feasibility was observed regarding this management tactic. In spite of the economic deficit, there was no statistical difference for the results of 2017. In the previous year, instead of an increase, a huge loss was established upon 
treating the Z-83, Z-85, and Z-87 phenological stages (for the second herbicide only) with glufosinate-ammonium and paraquat herbicides with economic damage being varying from $\mathrm{R} \$ 194$ to $\mathrm{R} \$ 989 \mathrm{ha}^{-1}$.

Upon analyzing the production of seeds from a practical point of view, seed mass and quality showed a direct relationship with each other. Heavier seeds are larger, thereby providing increased vigor and germination (Bredemeier et al., 2001). However, same authors added that the seedlings originated after shredding their peel have a higher rate of leaf emission and morphological attributes. Thus, it implies that this type of seed will excel even in adverse conditions in the field and is mainly related to the sowing process.

A physical analysis of the technological quality of the wheat, expresses the mass of the hectoliter in terms of shape, uniformity, density, and size of the grains (Rodrigues et al., 2011). With any of the tested herbicides, the treatment in humid conditions, with the moisture content being more than $45 \%$, leads to the reduction in the mass of the grains, while the application with humidity below $35 \%$ does not produce significant reduction effects (Mellado \& Pedreros, 2005). In the present study, the mass of the hectoliter did not get affected, however, the highest indices for this variable coincided with the higher moisture percentage indices. Further, the anticipation of the harvesting and drying of wheat grains does not interfere in the technological quality of the flour (Carneiro et al., 2005). Nevertheless, seeds harvested in more humid conditions are prone to undergo germination in the spike, thereby indicating that for their drying a forced process is required, which in turn increases the operating costs of the drying process.

The herbicides, glufosinate-ammonium, paraquat, and glyphosate, have the potential to promote desiccation of wheat leaves and stalks, hence anticipating their harvest in five days (Calviño et al., 2002). Further, Calviño et al. (2002) also reported a decrease in the moisture content of the grain mass with respect to the control treatment. Additionally, in connection with the present study, the comparison should be established at the same application time, i.e. after the Z-88 stage and both results were found to be in close agreement with each other regarding the potential of moisture reduction of seed mass. From these observations, it is evident that the greater contribution to the effect of the phenological stage of application depends on the type of herbicide and its dose, as the control treatment in the present study was significantly superior in comparison to the herbicides. The herbicides glufosinate-ammonium (4.8 days), glyphosate (2.1 days) and paraquat (5.3 days) showed little efficacy with no economic viability. These results are consistent with Pires et al. (2016) searching wheat-soybean succession strategies for the Rio Grande do Sul plateau. Increasingly, sustainability in the economic, environmental and social sense will be present in the decision making about whether or not to use pre-harvest management. Crop management actions should be based on economic and technical aspects that will avoid environmental contamination, as presented by the management proposals presented by Lodovichi et al. (2013).

Contemplating the cycle of the cultivars used in the south of the country, cultivars of the precocious and medium type prevails predominantly (Embrapa, 2017). Moreover, the 
development of wheat is directly proportional to temperature. In other words, a linear relationship between the average temperature and rate of development was observed, which facilitates the quantification of the duration of a few phases in a unit of thermal time (Rodrigues et al., 2011). Based on this information, one can infer that shorter the cycle of a cultivar, lower the harvest anticipation provided by desiccation. Sporadically, this practice is not applicable in the case of early cultivars, because the transition between the phenological stages depends on less thermal accumulation, leading to no anticipation.

In conformity with Bellé et al. (2014), the present research indicated that at phenological stages the timing of application was stratified, which are hard to identify precisely under field conditions. In this context, the visual aspects of plant coloring have also been proven to be inefficient, as changes in the leaf color are closely dependent on environmental conditions (Calviño et al., 2002). In the same plant, there are spikes with different stages of maturation, as well as, in the same spike, seeds in the same maturation stage are present, therefore, elucidating different dampness. Additionally, exploration of the representativeness of the samplings and the correct method of experimental analysis in a better way is essential (Darwent et al., 1994).

The application of non-selective herbicides in the pre-harvest wheat crop exhibits the following advantages: (i) low influence on the mass of the hectoliter, (ii) anticipation of harvest in relation to the control, and (iii) increase the efficiency of the mechanized harvest indirectly, by the uniformization of the maturation of the plant canopy. Nevertheless, it few disadvantages are also present such as (i) reduction in seed productivity and mass, (ii) providing a more humid seed harvest, and (iii) no economic feasibility in seed commercialization.

A significant reduction in wheat production was found to be in combination with the anticipation of harvest. Possibly, under certain circumstances penalizing the wheat production by virtue of allocating the subsequent crop in a better growing season can maximize its production. Further, from the view of plant ecophysiology and the economic aspect, it has been emphasized that one should consider this as a one-off situation. Therefore, these gaps need to be elucidated in future experiments, since the production system is constantly undergoing changes. Thus, conclusively the desiccation in the pre-harvest of the wheat is not recommended for the situations analyzed in the present research.

\section{Conclusion}

The application of non-selective herbicides such as glufosinate-ammonium ( $350 \mathrm{~g}$ ia ha $\left.{ }^{-1}\right)$ and paraquat ( $\left.400 \mathrm{~g}_{\text {ia ha }}{ }^{-1}\right)$ in the pre-harvest stage promoted greater phytotoxification of wheat, anticipating the harvest in 4.8 and 5.3 days, respectively.

A reduction in seed productivity and mass was demonstrated, with no economic feasibility in the case of both cultivars under evaluation. 


\section{References}

Alvares, C. A., Stape, J. L., Sentelhas, P. C., de Moraes Gonçalves, J. L., \& Sparovek, G (2013). Köppen's climate classification map for Brazil. Meteorologische Zeitschrift, 22(6), 711-728. https://doi.org/10.1127/0941-2948/2013/0507

Bellé, C., Kulczynski, S. M., Basso, C. J., Kaspary, T. E., Lamego, F. P., \& Pinto, M. A. B. (2014). Yield and quality of wheat seeds as a function of desiccation stages and herbicides. Journal of Seed Science, 36(1), 63-70. https://doi.org/10.1590/S2317-15372014000100008

Bredemeier, C., Mundstock, C. M., \& Büttenbender, D. (2001). Efeito do tamanho das sementes de trigo no desenvolvimento inicial das plantas e no rendimento de grãos. Pesquisa $\begin{array}{lll}\text { Agropecuária } \quad \text { Brasileira, } & 36(8), & 1061-1068 .\end{array}$ https://doi.org/10.1590/S0100-204X2001000800008

Cadenas, J. M., Garrido, M. C., Martines-Espanã, R. A., \& Guillén-Navarro, M. A. (2020). Making decisions for frost prediction in agricultural crops in a soft computing framework. Computers and Electronics in Agriculture, 175, 105587. https://doi.org/10.1016/j.compag.2020.105587

Calviño, P. A., Studdert, G. A., Abbate, P. E., Andrade, F. H., \& Redolatti, M. (2002). Use of non-selective herbicides for wheat physiological and harvest maturity acceleration. Field Crops Research, 77(2-3), 191-199. https://doi.org/10.1016/S0378-4290(02)00072-2

Carneiro, L. M. T. A., Biagi, J. D., Freitas, J. G., Carneiro, M. C., \& Felício, J. C. (2005). Diferentes épocas de colheita, secagem e armazenamento na qualidade de grãos de trigo comum e duro. Bragantia, 64(1), 127-137.

https://doi.org/10.1590/S0006-87052005000100014

Conab, Companhia Nacional do Abastecimento (2018). Levantamentos de safra, Available at: https://www.conab.gov.br/download/

Conab, Companhia Nacional do Abastecimento. (2016) Custos de produção - culturas de inverno, Available at:

http://www.conab.gov.br/uploads/culturas_inverno-mar-2016-resumo-site.xls

Cruz, C. D. (2013). GENES - a software package for analysis in experimental statistics and quantitative genetics. Acta Scientiarum. Agronomy, 35(3), 271-276. https://doi.org/10.4025/actasciagron.v35i3.21251

Darwent, A. L., Kirkland, K. J., Cessna, A. J., Lukowo, O. M., \& Lefkovitch, L. P. (1994). Effect of preharvest applications of glyphosate on the drying yield and quality of wheat. Canadian Journal of Plant Science, 74(2), 221-230. https://doi.org/10.4141/cjps94-046

Edwards, S. G., Kharbikar, L. L., Dickin, E. T., MacDonald, S., \& Scudamore, K. A. (2018). Impact of pre-harvest rainfall on the distribution of fusarium mycotoxins in wheat mill fractions. Food Control, 89(1), 150-156. https://doi.org/10.1016/j.foodcont.2018.02.009

Embrapa, Empresa Brasileira de Pesquisa Agropecuária (2018). Informações técnicas para 
trigo $e$ triticale, Available at: http://ainfo.cnptia.embrapa.br/digital/bitstream/item/155787/1/Informacoes-Tecnicas-para-Tri go-e-Triticale-Safra-2017-OL.pdf

Griffin, J. L., Boudreaux, J. M., \& Miller, D. K. (2010). Herbicides as Harvest Aids. Weed Science, 58(3), 355-358. https://doi.org/10.1614/WS-09-108.1

Janssen, E., Mourits, M., van der Fels-Klerx, H. J., \& Lansink, A. O. (2019). Pre-harvest measures against Fusarium spp. Infection and related mycotoxins implemented by Dutch wheat farmers. Crop Protection, 122(1), 9-18. https://doi.org/10.1016/j.cropro.2019.04.005

Krenchinski, F. H., Cesco, V. J. S., Rodrigues, D. M., Pereira, V. G. C., Albrecht, A. J, P., \& Albrecht, L. P. (2017). Yield and physiological quality of wheat seeds after desiccation with different herbicides. Journal of Seed Science, 39(3), 254-261. https://doi.org/10.1590/2317-1545v39n3172506

Large, E. C. (1954). Growth stages in cereals illustration of the Feekes scale. Plant Pathology, 3(4), 128-129. https://doi.org/10.1016/j.agsy.2013.07.006

Lodovichi, M. V., Blanco, A. M., Chantre, G. R., Bandoni, J. A., Sabbatini, M. R., Vigna, M., \& Gigón, R. (2013). Operational planning of herbicide-based weed management. Agricultural Systems, 121(1), 117-129. https://doi.org/10.1016/j.agsy.2013.07.006

Malalgoda, M. Ohm, J., Howatt, K. A., Green, A. \& Simsek, S. (2020a). Effects of pre-harvest glyphosate use on protein composition and shikimic acid accumulation in spring wheat. Food Chemistry, 127, 422. https://doi.org/10.1016/j.foodchem.2020.127422

Malalgoda, M., Ohm, J., Ransom, J. K., Howatt, K. \& Simsek, S. (2020). Effects of pre-harvest glyphosate application on spring wheat quality characteristics. Agriculture, 10(4), 111. https://doi.org/10.3390/agriculture10040111

Mellado, M. Z., \& Pedreros, A. L. (2005). Efecto de herbicidas aplicados durante lamadurezdel grano de trigo em el rendimiento y calidad del grano. Agricultura Técnica, 65(3), 312-318. https://doi.org/10.4067/S0365-28072005000300009

Perboni, L.T., Agostinetto, D., Vargas, L., Chechin, J., Zandoná, R.R. \& Farias, H.S. (2018). Yield, germination and herbicide residue in seeds of preharvest desiccated wheat. Journal of Seed Science. 40(3), 304-312. https://doi.org/10.1590/2317-1545v40n3191284

Pires, J. L. F., Strieder, M. L., Pereira, P. R. V. S., Costamilan, L. M., Maciel, J. L. N., de Mori, C., Pasinato, A. (2016). Estratégias de sucessão trigo/aveia preta-soja para sistemas de produção de grãos no Planalto Médio do Rio Grande do Sul, Available at http://ainfo.cnptia.embrapa.br/digital/bitstream/item/144792/1/ID43667-2016CTO30.pdf

Rodrigues, O., Teixeira, M. C. C., Costenaro, E. E., \& Sana, D. (2011). Ecofisiologia de trigo: bases para elevado rendimento de grãos. In J. L. F. Pires, L. Vargas, \& G. R. (Eds.) Trigo no Brasil: Bases para produção competitiva e sustentável (pp. 115-134). Passo Fundo, Embrapa Trigo. 


\section{Macrothink}

Journal of Agricultural Studies

ISSN 2166-0379

2021, Vol. 9, No. 2

Song, Y., Linderholm, H. W., Wang, C., Tian, J., Huo, Z, Gao, P., Song, Y., Guo, A. (2019). The influence of excess precipitation on winter wheat under climate change in China from 1961 to 2017. Science of The Total Environment, 690(1), 189-196. https://doi.org/10.1016/j.scitotenv.2019.06.367

Taiz, L., Zeiger, E., Moller, I., \& Murphy, A. (2017). Fisiologia e desenvolvimento vegetal. (6nd ed.). Porto Alegre: Artmed. p. 888.

Tavares, L.C., Oliveira, S., Silva, B.M., Lemes, E.S., Villela, F.A., Vargas, L. \& Agostinetto, D. (2018). Produtividade, qualidade fisiológica e resíduo em sementes de trigo em função da dessecação com herbicidas. Colloquium Agrariae, 14(3), 132-143. https://doi.org/10.5747/ca.2018.v14.n3.a235

Velini, E. D., Osipe, R., \& Grazziero, D. L. P. (1995). Procedimentos para instalação, avaliação e análise de experimentos com herbicidas. Londrina: SBCPD. p. 42.

Yenish, J. P., \&Young, F. L. (2000). Effect of Preharvest Glyphosate Application on Seed and Seedling Quality of Spring Wheat (Triticum aestivum). Weed Technology, 14(1), 212-217. https://doi.org/10.1614/0890-037X(2000)014[0212:EOPGAO]2.0.CO;2

Zadoks, J. C., Chang, T. T., \& Konzak, C. F. (1974). A decimal code for the growth stages of cereals. Weed Research, 14(1), 415-421. https://doi.org/10.1111/j.1365-3180.1974.tb01084.x

\section{Copyright Disclaimer}

Copyright for this article is retained by the author(s), with first publication rights granted to the journal.

This is an open-access article distributed under the terms and conditions of the Creative Commons Attribution license (http://creativecommons.org/licenses/by/4.0/). 